\title{
Lithium therapy in literature and art
}

\author{
Leczenie litem $w$ literaturze i sztuce \\ Janusz Rybakowski \\ Poznan University of Medical Sciences, Department of Adult Psychiatry
}

\begin{abstract}
Introduction. In 1949, Australian psychiatrist John Cade described a therapeutic action of lithium carbonate in mania. This date is regarded as an introduction of lithium into contemporary psychiatric therapeutics and the beginning of modern psychopharmacology. In the early 1960s, a prophylactic activity of lithium was observed, preventing recurrences of affective episodes in mood disorders. Lithium has become a prototype of the mood-stabilising drugs and remains a drug of the first choice for the prophylaxis of recurrences in bipolar mood disorder. Literature review. Both the introduction of lithium into psychiatric therapy and its therapeutic action has been
\end{abstract}

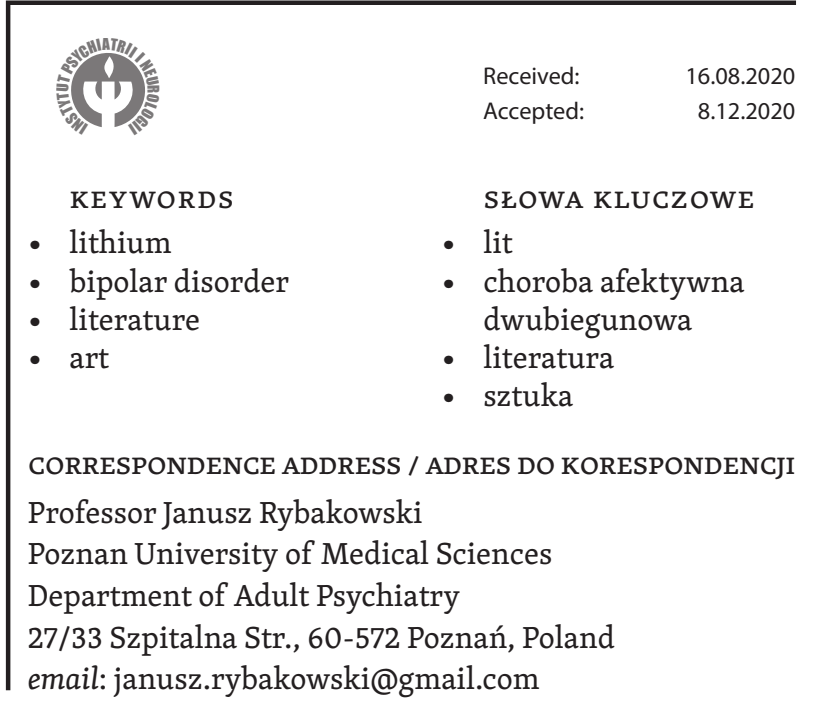

reflected in literature and art. This article presents the connections of lithium therapy with literature and art. They pertain to such characters as John Cade, Salvador Luria, Patty Duke, Kay Jamison, Jerzy Broszkiewicz, Ota Pavel, Robert Lowell, Jaime Lowe, Nicole Lyons, Kurt Cobain, Sting, and the band Evanescence.

Conclusions. Special attention was given to the book Unquiet mind, written in 1996 by Kay Jamison, professor of psychology. In the book, her personal bipolar disorder and lithium treatment were described from the viewpoint of the eminent professional. Polish translation of the book titled Niespokojny umyst already has two editions: in 2000 and 2018.

\section{STRESZCZENIE}

Wstęp. W 1949 roku australijski psychiatra John Cade opisał przeciwmaniakalne działanie węglanu litu. Datę tę traktuje się jako wprowadzenie litu do współczesnego lecznictwa psychiatrycznego oraz początek nowoczesnej psychofarmakologii. Na początku lat 60 . XX wieku zaobserwowano natomiast profilaktyczne działanie litu zapobiegające nawrotom epizodów afektywnych. Lit stał się prototypem leków normotymicznych (mood-stabilizing) i pozostaje lekiem pierwszego wyboru dla profilaktyki nawrotów w chorobie afektywnej dwubiegunowej.

Przegląd piśmiennictwa. Zarówno wprowadzenie litu do lecznictwa psychiatrycznego, jak i jego działanie terapeutyczne znalazło odzwierciedlenie w dziełach literackich i sztuce. W niniejszym artykule przedstawione zostaną powiązania terapii litem z literaturą i sztuką dotyczące takich postaci, jak John Cade, Salvador Luria, 
Patty Duke, Kay Jamison, Jerzy Broszkiewicz, Ota Pavel, Robert Lowell, Jamie Lowe, Nicole Lyons, Kurt Cobain, Sting i zespół rokowy Evanescence.

Wnioski. Na szczególną uwagę zasługuje książka profesor psychologii Kay Jamison Unquiet mind, z roku 1996,

\section{Introduction}

The work of the Australian psychiatrist John Cade (19121980) from 1949 is considered to be the first description of the therapeutic use of lithium in modern psychiatry (Cade, 1949). Some even consider it the beginning of modern psychopharmacology because it was three years ahead of French psychiatrists' report on the antipsychotic effects of chlorpromazine (Delay et al., 1952).

In his article, Cade presented a spectacular therapeutic effect of lithium carbonate in 10 manic patients. The administration of lithium salts to these patients was preceded by experiments on guinea pigs; Cade himself also took lithium carbonate, which convinced him that it did not cause significant toxic symptoms. Although, from the point of view of modern standards, this way of introducing the drug into clinical practice is a clear violation of the principles of good clinical practice, Cade's publication paved the way for lithium as one of the most important psychotropic drugs of today.

In the early 1960s, first works indicating the possibility of preventing the recurrence of affective disorders by using lithium were published. Their authors were British psychiatrist Geoffrey (Toby) Hartigan (1917-1968) (Hartigan, 1963) and Danish psychiatrist Poul Christian Baastrup (1918-2002) (Baastrup, 1964). Lithium has become a prototype of the mood-stabilising drug and is now considered the first-choice drug for the prevention of manic and depression relapses in affective disorders.

Both the introduction of lithium to psychiatric treatment and its therapeutic effect were reflected in literary works and art. This article presents the links of lithium therapy with literature and art concerning such characters as the already mentioned John Cade, as well as Alexander Luria, Patty Duke, Kay Jamison, Jerzy Broszkiewicz, Ota Pavel, Robert Lowell, Jaime Lowe, Nicole Lyons, Kurt Cobain, Sting, and the rock band Evanescence.

\section{Literature review}

\section{John Frederick Cade (1912-1980)}

The use of lithium in patients with mania was the result of a combination of the spirit of experimentation and clinical zeal in John Cade (Chiu and Hegarty, 1999), and w której po raz pierwszy indywidualne doświadczenie choroby afektywnej dwubiegunowej i leczenie litem opisała osoba będąca jednocześnie wybitnym profesjonalistą. Polskie tłumaczenie tej książki pt. Niespokojny umyst miało już dwa wydania: w roku 2000 i 2018.

his 1949 publication was cited more than 1000 times (according to the Scopus database). Terence Ketter, an American bipolar affective disorder specialist, proposed that the classic form of bipolar disorder (so-called type 1 bipolar affective disorder, with severe manic episodes) be given the eponym "Cade's disease" to commemorate the man who introduced the first effective therapeutic agent in this disease.

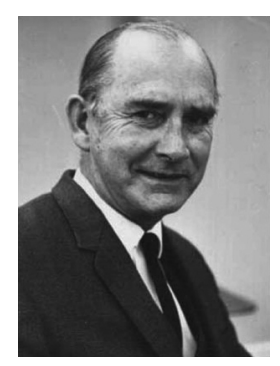

Figure 1 John Frederick Cade (1912-1980), a prominent Australian psychiatrist, author of a publication that appeared in the "Medical Journal of Australia" in 1949 and introduced the use of lithium to modern psychiatry

However, in the same year in which Cade described the therapeutic effects of lithium in mania, there were reports of fatal lithium poisoning in the USA when it was tried as a substitute for sodium in the so-called low-sodium diet (Corcoran et al., 1949). As a result, the U.S. Food and Drug Administration (FDA) issued a warning banning lithium salt for medicinal purposes. In 1950, however, it turned out that Bill Brand, whom Cade had been taking care of for several years and to whom he had administered lithium for the first time, died of complications related to the poisoning by this element. In the same year, Cade banned the use of lithium in his hospital, and stopped researching lithium in his further career and devoted himself mainly to teaching and organisational activities.

In 1963, Cade started corresponding with the Danish psychiatrist Mogens Schou, who proved to be the greatest researcher of lithium in the second half of the 20th century. Both researchers exchanged a lot of mutual praise. Schou complimented Cade on introducing lithium into psychiatry, and Cade praised Schou for his tireless research and advocacy of lithium therapy. In 1970 Cade visited the centre in Risskov, where Mogens Schou worked, and in 1978, he gave a laudation at the First British Lithium Congress held at Lancaster University. 
Due to the discovery of the therapeutic properties of lithium, Cade has won many national and international awards. Among the most important are the Order of Australia and the International Scientific Kitty Foundation Award, which he received in 1974, together with Mogens Schou. But his achievements were truly appreciated only in the 21st century, as evidenced by theatrical and film works and biographical books.

In 2003, a theatrical play Dr Cade was staged in Sydney for which the script was written by Neil Cole, the former Minister of Justice of Victoria, Australia, taking lithium for therapeutic purposes in connection with his own disorders. In 2004, the documentary Troubled minds: The lithium revolution was made based on the interviews with John Cade's sons, his patients, and other people involved in his life. The film won The International Vega Awards for popular science content.

John Cade himself has become the character of two books published in recent years. The first was written by Greg De Moore, a psychiatrist from Sydney, and by Ann Westmore, a health sociologist from Melbourne. It is called Finding sanity: John Cade, lithium and the taming of bipolar disorder. The book is a detailed biography of John Cade, from his childhood to his military service and being prisoner of war in Japan, and to the discovery of lithium and his further history. Much of the book is devoted to Cade's first "lithium" patient, Bill Brand, who died in 1950, probably from a lithium overdose (De Moore and Westmore, 2016).

In his book, Lithium: a doctor, a drug, and a breakthrough, published in 2019, American psychiatrist Walter Brown, who works at the Brown University in Providence, also devotes much space to John Cade's discovery of the therapeutic effects of lithium and its subsequent global consequences. He also discusses Cade's further history, which is hardly related to this landmark event. It is difficult for the author of the book to come to terms with the fact that after the famous 1949 publication, Cade stopped researching lithium and devoted himself to teaching and administrative activities, and continued his research interests, mainly concerning other elements, to a limited extent. He ceded the research on lithium to other researchers, mainly to Mogens Schou (Brown, 2019).

\section{Salvador Luria}

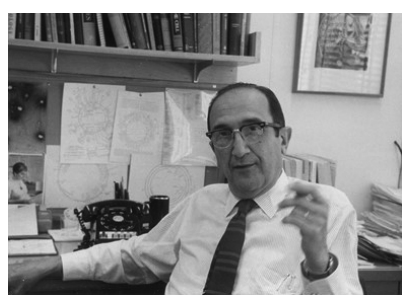

Figure 2 Salvador Luria (1912-1991), American scientist of Italian origin, 1969 Nobel Prize winner in physiology and medicine
Salvador Luria (1912-1991) was probably the first person to describe treating his own affective disorder in his autobiographical book published in 1984. The book was entitled: A slot machine, a broken test tube: an autobiography (Luria, 1984). Salvador Luria was born in Turin to a family of Sephardic Jews and graduated from the University of Turin in 1935. Due to the persecution of Jews by the Mussolini regime, he left Italy in 1938 and moved to France. In 1940, he emigrated to the USA, where he obtained citizenship in 1947. He conducted pioneering research on bacteriophages, for which he received the Nobel Prize in 1969.

In the last chapter of this book, entitled "Emotions," Luria describes his affective disorder as a frequently recurring depression that has been occurring since the 1950s. Episodes of depression occurred every few months, causing great suffering for him and his family. Many kinds of psychotherapy have proved to be ineffective. Prescribed in very low doses antidepressants also had no effect. It was not until the mid-1970s that the use of adequate doses of antidepressants, followed by preventive lithium treatment, resulted in a complete remission lasting 10 years, until the book was written.

\section{Patty Duke}

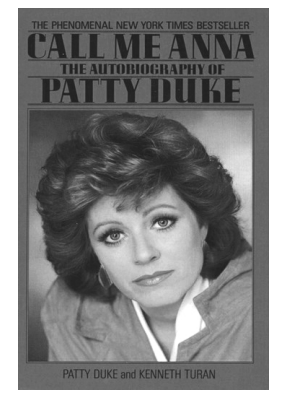

Figure 3 A book by the excellent American film actress Patty Duke (1946-2016), in which she describes her bipolar affective disorder and lithium treatment

In 1987, the book Call me Anna was published as an autobiography of the excellent American film actress Patty Duke (1946-2016) (Duke and Turan, 1987). She became famous as the youngest Oscar-winner in history. She received the prize at the age of 16 , in 1962, for her supporting role in Miracle Worker. In the book Call me Anna, the actress describes her illness, diagnosed in 1982 and the use of lithium treatment. The manic episode, after which she started to use lithium, occurred after injection of cortisol, administered to quickly fight hoarseness. In the book, the actress writes that she has fully accepted taking lithium for the rest of her life because it gives her a sense of certainty that there will be no changes in her mood that she has no control over.

Another autobiography by Patty Duke, written together with Gloria Hochman, was published in 1992 and was entitled A brilliant madness. Living with manic-depressive 
illness (Duke and Hochman, 1992). Patty Duke took lithium for the rest of her life and was extremely active in mental health education, especially bipolar affective disorder.

\section{Kay Jamison}

Kay Redfield Jamison is a trained psychologist and has worked as a professor at the Department of Psychiatry at Johns Hopkins University in Baltimore for many years. Together with Frederick Goodwin, former head of the U.S. National Institute of Mental Health, she is a co-author of the fundamental work on bipolar affective disorder, Manic-depressive disease. The first edition of the book was published in 1990 and was unanimously considered a "bipolar affective disorder bible" (Goodwin and Jamison, 1990). The second edition was published in 2007 and was entitled Manic-depressive illness. Bipolar disorders and recurrent depression. This was a reference to the concept of Manisch-depressives Irresein by Emil Kraepelin, who also included recurring depressive states in this category (Goodwin and Jamison, 2007).

Kay Jamison is not only an extremely prolific researcher but is also the author of very interesting books of popular science or even of fictional nature. They mostly refer directly or indirectly to the subject of bipolar affective disorder (manic depression). In her book, Touched with Fire. Manic-depressive illness and the artistic temperament, written in the early 1990s, she presented - based on the profiles of outstanding artists: poets, writers, musicians, and painters - her own analysis of the relationship between manic-depressive illness and creative activity (Jamison, 1993). A book called Night falls fast. Understanding suicide, published in 1999, is dedicated to the subject of suicide (Jamison, 1999). It was published in Polish in 2004 under the title Noc szybko nadchodzi. Zrozumieć samobójstwo, by mu zapobiec (Jamison, 2004).

In 1996, Kay Jamison's book An unquiet mind. A memoir of moods and madness became a great event in the USA. In this autobiographical publication, the author presented in a literary way a detailed account of her own successful struggle with manic depressive disorder and lithium treatment (Jamison, 1996). The publication of this book was an event, and probably also a challenge for both psychiatrists and numerous readers from all circles of the society. It was probably the first time that a person professionally involved in psychiatry and performing important university functions told about her mental illness.

From the perspective of this book, the author's descriptions concerning her history of long-term lithium treatment are particularly interesting. She started it in 1975, during a period of increased mood, and after 6 weeks she discontinued it. A manic episode occurred, followed by depressive episode, and then she resumed taking lithium. Later, she stopped taking the medicine several more times, and then there were states of a disturbed mood, i.e. "increased" or "depressed". Finally, after a few months, she started taking the drug systematically, which she probably continues to take until now. In the initial period of taking lithium, she had a digestive problem, which later subsided. According to her, her resistance to the use of lithium was more related to psychological factors than side effects. On the one hand, she says that she has become somehow "addicted" to increased moods, got used to the intensity of sensations, euphoria and confidence, and their infectious tendency to evoke good mood and enthusiasm in other people. On the other hand, due to her rather puritanical upbringing, she believed that she should be able to solve all her problems without relying on aids such as drugs.

At the end of the book, however, the author states: "I have often asked myself whether, given the choice, I would choose to have manic-depressive illness. If lithium were not available to me, or didn't work for me, the answer would be a simple no - and it would be an answer laced with terror. But lithium does work for me, and therefore I can afford to pose the question. Strangely enough I think I would choose to have it."

The account of the effect of lithium dose reduction on cognitive functions is also interesting: "A few days after lowering my dose, I was walking in Hyde Park, along the side of the Serpentine, when I realized that my steps were literally bouncier than they had been and that I was taking in sights and sounds that previously had been filtered through thick layers of gauze. The quacking of the ducks was more insistent, clearer, and more intense; the bumps on the sidewalk were far more noticeable; I felt more energetic and alive. Most significant, I could once again read without effort. It was, in short, remarkable." Due to the fictional nature of the account, the author does not give the amount of higher and lower dose of lithium or the concentration of lithium obtained with these doses. This could be important from the point of view of the lithium treatment practice.
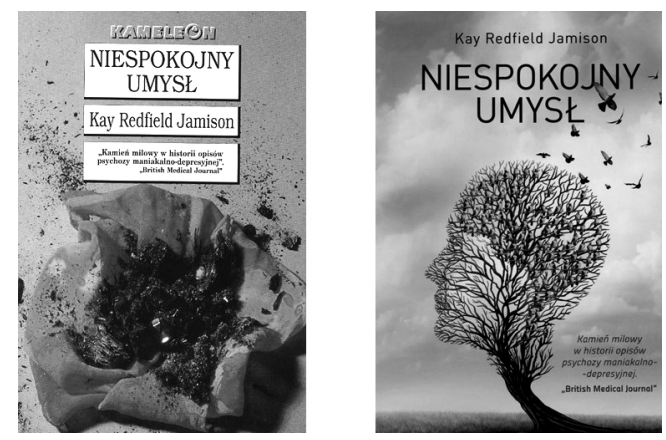

Figure 4 Covers of Polish editions of An unquiet mind (Niespokojny umysł), 2000 and 2018

For Polish readers Niespokojny umyst has been available since 2000, when the local edition of the book was published by the Poznań publishing house Zysk i Spółka. 
The translation was done by Filip Rybakowski, the current head of the Department of Adult Psychiatry at the Poznan University of Medical Science, and the author of this article wrote the afterword (Jamison, 2000). Due to the book rapidly going out of print and continuous questions of interested parties, Zysk i Spółka Publishing House decided to publish the second edition of the book in 2018 (Jamison, 2018).

\section{Jerzy Broszkiewicz}

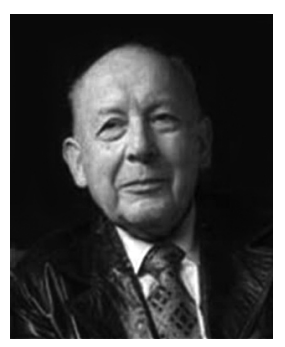

Figure 5 Jerzy Broszkiewicz (1922-1993), an excellent prose writer and playwright. He describes lithium treatment in his novel Doktor Twardowski

Among outstanding Polish writers suffering from bipolar affective disorder and receiving lithium treatment, there is Jerzy Broszkiewicz (1922-1993), a prose writer, playwright, essayist and publicist, and the author of science fiction. He described lithium therapy in the title character of his novel Dr Twardowski (Broszkiewicz, 1979). Broszkiewicz was psychiatrically hospitalised several times, among others in the Psychiatry Clinic in Poznań. His wife, Ewa Broszkiewicz (1920-2000), an excellent psychiatrist from Cracow, was one of the people involved in introducing lithium to the treatment of affective diseases in our country.

\section{Ota Pavel}

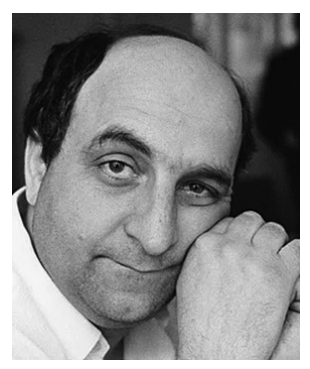

Figure 6 Ota Pavel (1930-1973), Czech writer, journalist and sports reporter

Ota Pavel, born Otto Popper (1930-1973), was born in Prague to a family of a Jewish salesman - Leo Popper. His biography has recently been presented in a book published in our country, Ota Pavel - pod powierzchniq
(Kaczorowski, 2018). Pavel's most famous book is Smrt krásnŷch srnců (The Death of the Beautiful Roebucks), which has numerous editions in Poland; it was also the basis for a film.

In the early 1950s, Pavel experienced a nervous breakdown, probably an episode of depression, during his military service. In 1964, when Pavel was a correspondent at the Winter Olympics in Innsbruck, he had a manic episode with psychotic symptoms of delusions of grandeur and of persecution. The writer was hospitalised in Prague, and then repeatedly in various psychiatric hospitals; he was treated with electroshock therapy and pharmacological treatment, but no significant improvement was achieved. In 1967, Dr Pavel Grof, a young psychiatrist from the clinic in Bohnice, a district of Prague, offered him treatment with lithium carbonate and it brought about a spectacular improvement. Ota Pavel told about this event in a letter to his brother Hugo: "One day a miracle happened. A MIRACLE. My doctor came holding in his hand a new, wonderful drug. And then he shook my hand and let me out of the clinic." In the following years, Pavel took lithium and wrote his best works. According to the account of his son, an important side effect of lithium therapy was excessive thirst, resulting in drinking large amounts of fluids and significant weight gain. In 1973, the writer's somatic condition collapsed suddenly, but instead of being taken to the intensive care unit, he was taken to the psychiatric ward where he died.

Pavel (Paul) Grof, mentioned above, emigrated to Canada in 1968, where he is currently a professor at the University of Ottawa. He is one of the most eminent researchers of lithium. In 1988, together with Mogens Schou from Denmark and Bruno Müller-Oerlinghausen from Berlin, he contributed to the establishment of the International Group for The Study of Lithium Treated Patients (IGSLI). In the article written for the 50th anniversary of modern lithium therapy, he introduced the concept of excellent lithium respondents, meaning patients in whom the use of lithium as the only mood-stabilising drug prevents relapses throughout the entire period of its application, often 20 years and more, as if the disease simply ceased to exist (Grof, 1999).

\section{Robert Lowell}

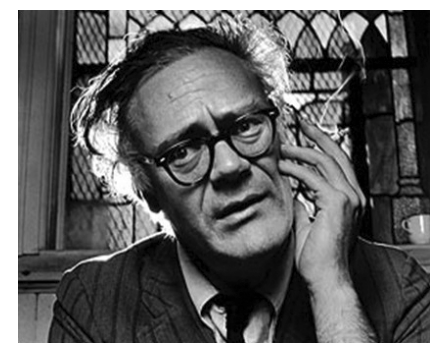

Figure 7 Robert Lowell (1917-1977), one of the greatest American poets of the 20th century, treated with lithium for the last 10 years of his life 
For the last 10 years of his life, Robert Lowell (19171977), one of the greatest American poets of the 20th century, was treated with lithium. His biography was recently presented by Kay Jamison in his book Robert Lowell, setting the river on fire. A study of genius, mania, and character (Jamison, 2017). Lowell's illness began in 1949 with a violent maniacal state with psychotic symptoms, for which he was hospitalised at Baldpate Hospital in Georgetown, Massachusetts. He later stayed several times in various psychiatric hospitals, including in 1958 at McLean Hospital, formerly known as McLean Asylum for the Insane, where his great-grandmother Harriet Lowell was hospitalised in 1845 . Lowell started using lithium in 1967. After a year of using it, he wrote: "The pills I am taking really seem to prevent mania (...). Ordinarily, I would have certainly been in a hospital by now. The great thing is that even my well life is much changed, as tho I'd once been in danger of falling with every stop I took. All the psychiatry and therapy I've had, almost 19 years was as irrelevant as it would have been for a broken leg" (Jamison, 2017). Lithium therapy worked very well for Lowell and when he discontinued using lithium for a short time in 1975, it resulted in two more hospitalisations.

\section{Jaime Lowe}

Recent autobiographical books on lithium therapy include a work by an American writer Jaime Lowe, entitled Mental: lithium, love and losing my mind, published in 2017 (Lowe, 2017). Two years before, on 25 June 2015, in The New York Times Magazine, she presented her lithium treatment as well as the history and glorification of lithium treatment in the article under the provocative title I don't believe in God but I believe in lithium. Jaime Lowe started lithium treatment after she experienced psychotic mania at the age of 16 . Since then, the author had continued this treatment for 7 years. In the meantime, she graduated from the University of California's Faculty of Arts and English Language. In 2000, she attempted to stop using lithium, which resulted in an intensified manic episode. She started to take lithium again, and for the next 13 years, she enjoyed her well-being, was creatively active and travelled a lot. There is no mention of any follow-up checks by a psychiatrist and measuring lithium concentration during that period. In the autumn of 2014, on behalf of a general practitioner, she was consulted in the emergency room, where elevated blood pressure, high creatinine levels, and symptoms of kidney damage were found. Her nephrologist recommended that she stop using lithium and switch to some other mood-stabilising drug. He found that her kidneys function at only $50 \%$ and, if she did not stop taking lithium, she would be at risk of dialysis and a kidney transplant within 10 years. The author has gradually switched to valproate (Depakote). However, in her book, she is still optimistic about lithium. It seems that optimism could be more justified if lithium treatment between 2001 and 2014 was carried out under the control of a psychiatrist, with periodic measurements of concentration and the required laboratory tests.

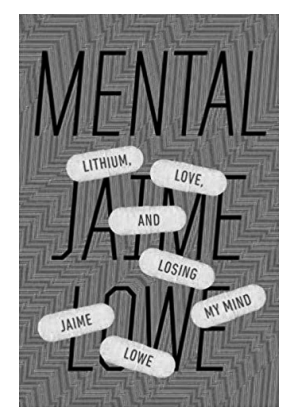

Figure 8 The cover of Jaime Lowe's 2017 book Mental: lithium, love and losing my mind

\section{Nicole Lyons}

Lithium therapy is mentioned in the last selection of poems by Canadian poet Nicole Lyons entitled The lithium chronicles (Lyons, 2019). Nicole has been struggling with the bipolar affective disorder for several years, but she is convinced that the disease can be an opportunity to live better and happier. She also created a Facebook page "The Lithium Chronicles" for this purpose. She is a keen advocate of addressing mental health issues and preventing suicide in young people.

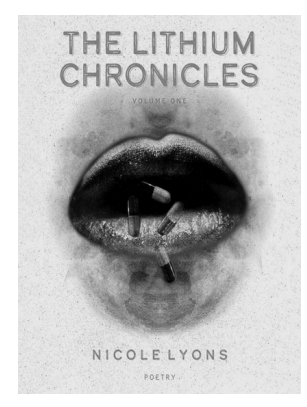

Figure 9 The cover of the 2019 Nicole Lyone poetry collection The lithium chronicles

\section{Kurt Cobain}

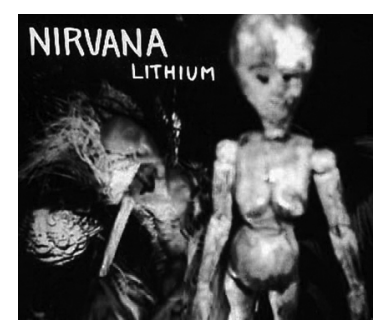

Figure 10 Cover of the album of Nirvana with Kurt Cobain's song "Lithium" 
The song called "Lithium" was written in 1992 by the outstanding American rock musician Kurt Cobain (19671994), a guitarist and vocalist of the iconic band Nirvana. Cobain suffered from a bipolar affective disorder, was a heroin addict, and probably died a suicidal death. The title of the song refers to a therapeutic agent, of which Cobain was aware, but unfortunately, he never decided to use it.

\section{Sting}

The song "Lithium Sunset" was written in 1996 and is sung by the famous English singer Gordon Sumner performing under the pseudonym Sting. The song refers to the therapeutic properties of lithium in manic depression, among others in the lyrics "heal my soul, o, lithium sunset" and "take this lonesome burden of worry from my mind". Probably the motivation for the creation of this song was to help people suffering from this disease.

\section{Evanescence}

In 2006, the American rock band Evanescence recorded the song "Lithium". It was written by Amy Lee, the vocalist of the band. The message is quite perverse - as if the author did not want lithium to take away her emotions, including negative ones: "Lithium, I want to stay in love with my sorrow." Lee admits that this is a kind of metaphor for experiencing happiness and the relationship between artistic creation and emotions.

\section{Overview}

This article shows how important lithium has proved to be in psychiatry and how its extraordinary properties are praised by those who were enabled by it to lead a good, creative, fulfilled life, and perhaps whose life was saved by it.

The article first introduces the Australian psychiatrist John Cade, thanks to whom everything started 71 years ago. Although he was only an initiator of the lithium therapy in modern psychiatry, after 50 years, this fact

\footnotetext{
Wstęp

Praca australijskiego psychiatry Johna Cade’a (1912-1980) z roku 1949 uważana jest za pierwszy opis terapeutycznego zastosowania litu we współczesnej psychiatrii (Cade, 1949). Niektórzy uznają ją nawet za początek współczesnej psychofarmakologii, ponieważ wyprzedzała o trzy lata relację francuskich psychiatrów dotyczącą
}

alone has already gained recognition and is reflected in literature and art.

The paper presents the profiles of prominent people from the field of literature, science, and art who took lithium. In some of them, the clinical effects of lithium exceeded the effectiveness of previous, sometimes longterm therapies. That is how Salvador Luria, Ota Pavel, and Robert Lowell reported it. Jaime Lowe's lithium therapy allowed her to complete her studies and conduct creative activities.

Observations made by these persons themselves or by their relatives also indicate significant side effects during long-term lithium therapy. Ota Pavel, according to his son's account, suffered from excessive thirst and drank large amounts of fluids. He also experienced significant weight gain. After several years of using lithium, Jaime Lowe suffered from kidney damage (interstitial nephropathy), which necessitated a change from lithium to another mood-stabilising drug (valproate).

The last three examples show that the lithium has also entered the world of pop culture, and has become an inspiration for the music of Kurt Cobain, Sting, and the rock band Evanescence. Thus, it can be concluded that the relationship between lithium treatment and literature and art is remarkable and worthy of presentation.

Does lithium consumption affect creative activity? In 1979, the work of the outstanding lithium researcher Mogens Schou on this subject was published, which included 24 artists. It turned out that half of them indicated an increase in artistic productivity during lithium therapy, six reported a slight decrease in productivity, and other six did not notice any change (Schou, 1979). A few years later, Shaw et al. (1986), when studying people with the bipolar affective disorder during the euthymic period, showed that lithium can reduce the ability for creative associations. However, as reported by people taking lithium, despite the periodic decrease of creative inspiration in some, lithium use has a beneficial effect on the course of the disease, preventing affective episodes that may have generally negative consequences for life. As a result, this generally translates into better functioning in many spheres, including creativity.

przeciwpsychotycznego działania chlorpromazyny (Delay i wsp., 1952).

W swoim artykule Cade przedstawił spektakularne działanie lecznicze węglanu litu u 10 chorych w stanie maniakalnym. Podanie soli litu tym pacjentom zostało poprzedzone eksperymentami na świnkach morskich oraz zażyciem węglanu litu przez samego Cade’a, który w ten sposób przekonał się, że nie powoduje on istotnych 
objawów toksycznych. Mimo iż z punktu widzenia współczesnych standardów ten sposób wprowadzenia leku do praktyki klinicznej stanowi jawne pogwałcenie zasad good clinical practice, publikacja Cade'a utorowała drogę dla litu jako jednego z najważniejszych obecnie leków psychotropowych.

$\mathrm{Na}$ początku lat 60 . XX wieku pojawiły się prace wskazujące na możliwość zapobiegania nawrotom chorób afektywnych dzięki zastosowaniu litu. Ich autorami byli psychiatra brytyjski Geoffrey (Toby) Hartigan (1917-1968) (Hartigan, 1963) oraz psychiatra duński Poul Christian Baastrup (1918-2002) (Baastrup, 1964). Lit stał się prototypem leku normotymicznego (mood-stabilizing) i w chwili obecnej jest uważany jako lek pierwszego wyboru dla zapobiegania nawrotom manii i depresji w chorobach afektywnych.

Zarówno wprowadzenie litu do lecznictwa psychiatrycznego, jak i jego działanie terapeutyczne znalazło odzwierciedlenie w dziełach literackich i sztuce. W niniejszym artykule przedstawione zostaną powiązania terapii litem z literaturą i sztuką dotyczące takich postaci, jak wspomniany już John Cade, a także Alexander Luria, Patty Duke, Kay Jamison, Jerzy Broszkiewicz, Ota Pavel, Robert Lowell, Jamie Lowe, Nicole Lyons, Kurt Cobain, Sting oraz zespół rockowy Evanescence.

\section{Przegląd literatury}

John Frederick Cade (1912-1980)

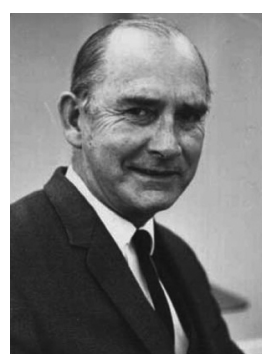

Rycina 1 John Frederick Cade (1912-1980), wybitny australijski psychiatra, autor publikacji, która ukazała się w "Medical Journal of Australia" w 1949 roku i zapoczątkowała stosowanie litu we współczesnej psychiatrii

Zastosowanie litu u pacjentów w stanie maniakalnym było efektem połączenia ducha eksperymentowania i zapału klinicznego u Johna Cade'a (Chiu i Hegarty, 1999), a jego publikacja z roku 1949 została zacytowana ponad 1000 razy (wedle bazy danych Scopus). Amerykański specjalista od choroby afektywnej dwubiegunowej Terence Ketter zaproponował, aby klasycznej postaci choroby maniakalno-depresyjnej (tzw. chorobie afektywnej dwubiegunowej typu I, przebiegającej z nasilonymi stanami maniakalnymi) nadać eponim "choroba Cade'a” (ang. Cade's disease), dla uczczenia pamięci człowieka, który wprowadził pierwszy skuteczny w tej chorobie środek terapeutyczny.

Jednak w tym samym roku, w którym Cade opisał terapeutyczne działanie litu w manii, w USA pojawiły się opisy śmiertelnych zatruć litem, gdy próbowano go stosować jako substytut sodu w tzw. diecie niskosodowej (Corcoran i wsp., 1949). W rezultacie amerykańska Agencja Żywności i Leków (Food and Drug Administration, FDA) sformułowała ostrzeżenie zakazujące stosowania soli litu w celach leczniczych. Natomiast w roku 1950 okazało się, że Bill Brand, którym Cade opiekował się przez kilka lat i u którego po raz pierwszy zastosował lit, zmarł wskutek powikłań związanych z zatruciem tym pierwiastkiem. W tym samym roku Cade wydał zakaz stosowania litu w swym szpitalu, a w swej dalszej karierze zaprzestał badań nad litem i poświęcił się głównie działalności dydaktycznej i organizacyjnej.

W 1963 roku Cade nawiązał korespondencję z duńskim psychiatrą Mogensem Schou, który okazał się największym badaczem litu drugiej połowy XX wieku. Obaj badacze wymieniali liczne wzajemne pochwały. Schou komplementował Cade'a z powodu wprowadzenia litu do psychiatrii, a Cade chwalił Schou za jego niestrudzone badania i orędownictwo w zakresie terapii litem. W 1970 roku Cade odwiedził ośrodek w Risskov, gdzie pracował Mogens Schou, a w roku 1978 wygłosił pod jego adresem laudację na pierwszym brytyjskim kongresie na temat litu (First British Lithium Congress), jaki odbył się na uniwersytecie Lancaster.

W związku z odkryciem terapeutycznych właściwości litu Cade był laureatem wielu odznaczeń krajowych i międzynarodowych. Z najważniejszych należy wymienić Order of Australia oraz International Scientific Kitty Foundation Award, którą otrzymał w roku 1974, wspólnie z Mogensem Schou. Ale prawdziwie doceniono jego osiągnięcia dopiero w XXI wieku, czemu dają wyraz dzieła teatralne i filmowe oraz książki o charakterze biograficznym.

W roku 2003 została w Sydney wystawiona sztuka teatralna pt. Dr Cade, do której scenariusz napisał Neil Cole, były minister sprawiedliwości stanu Wiktoria w Australii, przyjmujący lit w celach terapeutycznych w związku z własnymi zaburzeniami. W roku 2004 powstał film dokumentalny pt. Troubled minds: The lithium revolution („Zaburzone umysły. Rewolucja związana z litem") oparty na wywiadach z synami Johna Cade’a oraz z jego pacjentami i innymi osobami z jego otoczenia. Film zdobył nagrodę The International Vega Awards za treści popularnonaukowe.

Natomiast sam John Cade stał się bohaterem dwóch książek opublikowanych w ostatnich latach. Pierwszą z nich napisali psychiatra z Sydney, Greg De Moore, i socjolog zdrowia z Melbourne, Ann Westmore. Nosi ona tytuł Finding sanity: John Cade, lithium and the taming of bipolar disorder („Odnajdowanie zdrowia psychicznego: John Cade, lit i okiełznanie choroby afektywnej 
dwubiegunowej"). Książka stanowi szczegółową biografię Johna Cade’a, od dzieciństwa, po służbę wojenną i niewolę japońską, aż po odkrycie litu i dalsze jego losy. Wiele miejsca w książce poświęcono pierwszemu „litowemu” pacjentowi Cade’a, jakim był Bill Brand, który zmarł w 1950 roku, prawdopodobnie z powodu przedawkowania litu (De Moore i Westmore, 2016).

Amerykański psychiatra Walter Brown, pracujący na Brown University w Providence w książce Lithium: a doctor, a drug, and a breakthrough (Lit: lekarz, lekarstwo i przełom), wydanej w 2019 roku, również wiele miejsca poświęca odkryciu terapeutycznego działania litu przez Johna Cade'a, a następnie jego konsekwencjom ogólnoświatowym. Omawia również dalsze losy Cade’a, które w niewielkim stopniu związane są już z tym przełomowym wydarzeniem. Autorowi książki trudno jest pogodzić się z faktem, że po słynnej publikacji z 1949 roku Cade zaprzestał badań nad litem, a poświęcił się działalności dydaktycznej i administracyjnej i w niewielkim stopniu kontynuował zainteresowania badawcze, głównie dotyczące innych pierwiastków. Badania nad litem scedował na innych badaczy, głównie na Mogensa Schou (Brown, 2019).

\section{Salvador Luria}

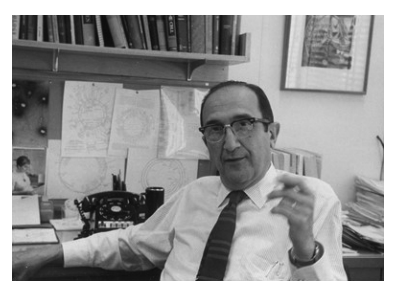

Rycina 2 Salvador Luria (1912-1991), amerykański uczony włoskiego pochodzenia, laureat Nagrody Nobla w dziedzinie fizjologii i medycyny z 1969 roku

Prawdopodobnie jako pierwszy leczenie litem swojej własnej choroby afektywnej opisał w autobiograficznej książce wydanej w roku 1984 Salvador Luria (1912-1991). Książka nosiła tytuł: A slot machine, a broken test tube: An autobiography („Automat do gier i zbita probówka: autobiografia"), (Luria, 1984). Salvador Luria urodził się w Turynie, w rodzinie Żydów sefardyjskich i ukończył uniwersytet turyński w roku 1935. W związku z prześladowaniem Żydów przez reżim Mussoliniego, w roku 1938 opuścił Włochy i przeniósł się do Francji, a w 1940 emigrował do USA, gdzie w roku 1947 uzyskał obywatelstwo. Prowadził pionierskie badania nad bakteriofagami, za które w roku 1969 roku otrzymał nagrodę Nobla.

W ostatnim rozdziale wspomnianej książki zatytułowanym „Emotions” Luria opisuje swoją chorobę afektywną jako częste nawracające depresje występujące od lat 50. XX wieku. Epizody depresji występowały co kilka miesięcy, powodując wielkie cierpienie dla niego i jego rodziny. Próby wielu psychoterapii okazały się nieefektywne. Leki przeciwdepresyjne przepisywano mu w bardzo niskich dawkach, również bez efektu. Dopiero w połowie lat 70. zastosowanie adekwatnych dawek leków przeciwdepresyjnych, a następnie profilaktyczne leczenie litem przyniosło całkowitą remisję trwającą 10 lat, do czasu napisania książki.

\section{Patty Duke}

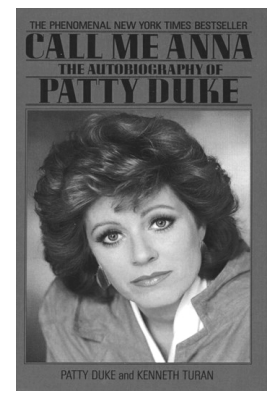

Rycina 3 Książka znakomitej amerykańskiej aktorki filmowej Patty Duke (1946-2016), w której opisała ona swoją chorobę afektywną dwubiegunową i leczenie litem

W roku 1987 ukazała się książka Call me Anna („Nazywaj mnie Anna") stanowiąca autobiografię znakomitej amerykańskiej aktorki filmowej Patty Duke (1946-2016), (Duke i Turan, 1987). Zasłynęła ona jako najmłodsza w historii zdobywczyni Oscara. Otrzymała ją w wieku 16 lat, w 1962 roku, za rolę drugoplanową w filmie Cudotwórczyni (Miracle worker). W książce Call me Anna aktorka opisuje swoją chorobę, rozpoznaną w roku 1982 oraz stosowanie litu w celu jej leczenia. Epizod manii, po którym rozpoczęła stosowanie litu, wystąpił po zastrzyku kortyzolu, podanego w celu szybkiego zwalczenia chrypki. W książce aktorka pisze, że w pełni zaakceptowała przyjmowanie litu do końca życia, gdyż daje jej to poczucie pewności, że nie wystąpią zmiany samopoczucia, nad którymi nie ma kontroli.

Kolejna autobiografia Patty Duke, napisana wspólnie z Glorią Hochman, ukazała się w 1992 roku i nosiła tytuł A brilliant madness. Living with manic-depressive illness („Znakomite szaleństwo. Życie z chorobą maniakalno-depresyjną"), (Duke i Hochman, 1992). Patty Duke do końca życia zażywała lit i była niezwykle czynna w zakresie edukacji na temat zdrowia psychicznego, w szczególności choroby afektywnej dwubiegunowej

\section{Kay Jamison}

Kay Redfield Jamison jest z wykształcenia psycholożką, od wielu lat pracuje jako profesor w Katedrze Psychiatrii Uniwersytetu Johnsa Hopkinsa w Baltimore. Wspólnie z Frederickiem Goodwinem, byłym szefem Narodowego Instytutu Zdrowia Psychicznego USA, jest współautorką fundamentalnego dzieła na temat choroby afektywnej dwubiegunowej pt. Manic-depressive illness. Pierwsze wydanie książki ukazało się w 1990 roku i zostało zgodnie 
uznane za biblię choroby afektywnej dwubiegunowej (Goodwin i Jamison, 1990). Druga edycja pojawiła się w 2007 roku i nosiła tytuł Manic-depressive illness. Bipolar disorders and recurrent depression. Było to nawiązanie do koncepcji manisch-depressives Irresein Emila Kraepelina, który do tej kategorii włączył również nawracające stany depresyjne (Goodwin i Jamison, 2007).

Kay Jamison prowadzi nie tylko niezwykle płodną działalność badawczą, ale jest też autorką bardzo interesujących książek o charakterze popularno-naukowym czy wręcz beletrystycznym. W większości nawiązują one pośrednio lub bezpośrednio do tematyki choroby afektywnej dwubiegunowej (maniakalno-depresyjnej). W swej książce Touched with fire. Manic-depressive illness and the artistic temperament („Dotknięci ogniem. Choroba maniakalno-depresyjna i temperament artystyczny”) napisanej na początku lat 90. XX wieku przedstawiła - na podstawie sylwetek wybitnych twórców: poetów, pisarzy, muzyków i malarzy - własną analizę związku między chorobą maniakalno-depresyjną a aktywnością twórczą (Jamison, 1993). Książka pt. Night falls fast. Understanding suicide wydana w roku 1999 poświęcona jest tematowi samobójstwa (Jamison, 1999). W polskim tłumaczeniu ukazała się w roku 2004 pod tytułem Noc szybko nadchodzi. Zrozumieć samobójstwo, by mu zapobiec (Jamison, 2004).

W roku 1996 wielkim wydarzeniem w USA stała się książka Kay Jamison pt. An unquiet mind. A memoir of moods and madness (Niespokojny umyst. Pamiętnik nastrojów i szaleństwa). W publikacji tej, mającej charakter autobiograficzny, autorka przedstawiła w sposób literacki szczegółowy zapis swoich własnych udanych zmagań z chorobą maniakalno-depresyjną i leczenia litem tej choroby (Jamison, 1996). Pojawienie się tej książki stanowiło wydarzenie, a prawdopodobnie i wyzwanie zarówno dla psychiatrów, jak i dla rzeszy czytelników z wszystkich kręgów społeczeństwa. Prawdopodobnie po raz pierwszy o swojej chorobie psychicznej opowiedziała osoba zawodowo związana z psychiatrią i pełniąca ważne funkcje uniwersyteckie.

Z perspektywy niniejszej książki szczególnie ciekawe są opisy autorki dotyczące jej historii długotrwałego leczenia litem. Rozpoczęła je w 1975 roku, w okresie podwyższonego nastroju i po 6 tygodniach odstawiła. Wystą̧ił stan maniakalny, a później depresji, kiedy to wznowiła przyjmowanie litu. Później jeszcze kilkakrotnie lek odstawiała, a wtedy występowały stany zaburzonego nastroju: „wyżu” lub „niżu”. Wreszcie, po kilku miesiącach, rozpoczęła systematyczne zażywanie leku, które prawdopodobnie kontynuuje do chwili obecnej. W początkowym okresie wprowadzania litu miała dolegliwości pokarmowe, które później ustępowały. Jak twierdzi, jej opór wobec zażywania litu był bardziej związany z czynnikami psychologicznymi niż objawami ubocznymi. $Z$ jednej strony podaje, że stała się w jakimś sensie „uzależniona” od podwyższonych nastrojów, przyzwyczaiła się do intensywności doznań, euforii i uczucia pewności, oraz ich zaraźliwej skłonności do wywoływania dobrego nastroju i entuzjazmu u innych ludzi. Z drugiej zaś w związku z otrzymanym dość purytańskim wychowaniem uważała, że powinna być zdolna do rozwiązywania wszystkich swoich problemów bez polegania na podpórkach takich jak leki.

Pod koniec książki autorka stwierdza jednak: „Często zadaję sobie pytanie, czy gdybym mogła wybrać, zdecydowałabym się na moją chorobę. Jeśli nie miałabym do dyspozycji litu lub gdyby lek ten skutecznie na mnie nie działał, odpowiedź brzmiałaby po prostu nie - i byłaby to na pewno odpowiedź zabarwiona przerażeniem. Ale lit działa na mnie korzystnie i z tego względu wydaje mi się, że takie pytanie mogę postawić. To dziwne, ale myślę, że prawdopodobnie zdecydowałabym się chorować na psychozę maniakalno-depresyjną."

Interesująca jest też relacja dotycząca wpływu zmniejszenia dawki litu na funkcje poznawcze: „W kilka dni po obniżeniu dawki spacerowałam w Hyde Parku wzdłuż Serpentyny, gdy uświadomiłam sobie, że poruszam się znacznie zgrabniej niż dotąd oraz że odbieram obrazy i dźwięki, które uprzednio jak gdyby zatrzymywały się na grubym filtrze. Kwakanie kaczek było bardziej natarczywe, wyraźnie intensywniejsze; znacznie lepiej dostrzegałam nierówności chodnika; czułam w sobie więcej energii i życia. A co najważniejsze, odtąd mogłam znowu czytać bez wysiłku. Mówiąc w skrócie, było to ważne wydarzenie". Ze względu na beletrystyczny charakter relacji autorka nie podaje wysokości wyższej i niższej dawki litu ani stężenia litu uzyskanego przy tych dawkach. A z punktu widzenia praktyki leczenia litem mogłoby to mieć istotne znaczenie.

Dla polskich czytelników Niespokojny umyst stał się dostępny od 2000 roku, kiedy to rodzime wydanie książki ukazało się nakładem poznańskiej oficyny wydawniczej Zysk i Spółka. Przekładu dokonał Filip Rybakowski, obecny kierownik Kliniki Psychiatrii Dorosłych Uniwersytetu Medycznego w Poznaniu, a autor niniejszego artykułu napisał posłowie (Jamison, 2000). Ze względu na szybkie wyczerpanie nakładu i ciągłe pytania osób zainteresowanych, wydawnictwo Zysk i Spółka zdecydowało się na drugą edycję książki w roku 2018 (Jamison, 2018).
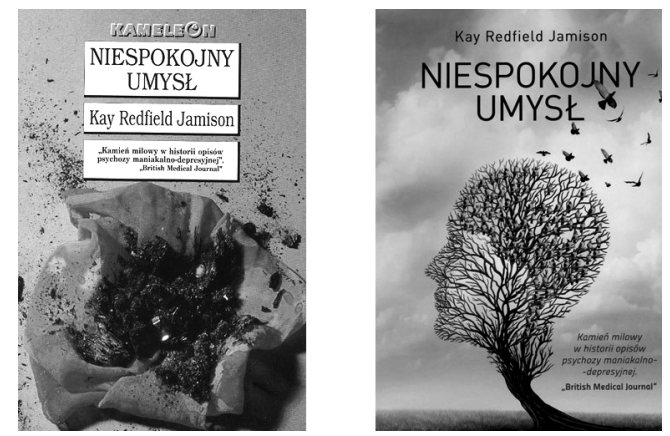

Rycina 4 Okładki polskich wydań Niespokojnego umysłu, z 2000 i 2018 roku 


\section{Jerzy Broszkiewicz}

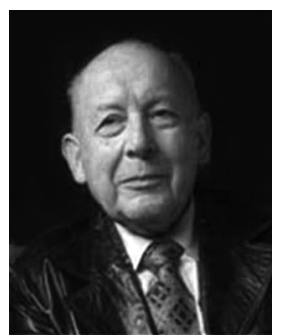

Rycina 5 Jerzy Broszkiewicz (1922-1993), znakomity prozaik i dramatopisarz. Leczenie litem opisał w powieści Doktor Twardowski

Wśród wybitnych polskich literatów cierpiących na chorobę afektywną dwubiegunową i otrzymujących leczenie litem można wymienić Jerzego Broszkiewicza (1922-1993), prozaika, dramatopisarza, eseisty i publicysty oraz autora fantastyki naukowej. Terapię litem opisał on u tytułowego bohatera swojej powieści Doktor Twardowski (Broszkiewicz, 1979). Broszkiewicz był kilkakrotnie hospitalizowany psychiatrycznie, m.in. w Klinice Psychiatrii w Poznaniu. Jego żona, Ewa Broszkiewicz (1920-2000), znakomity psychiatra z Krakowa, była jedną z osób zaangażowanych we wprowadzenie litu do leczenia chorób afektywnych w naszym kraju.

\section{Ota Pavel}

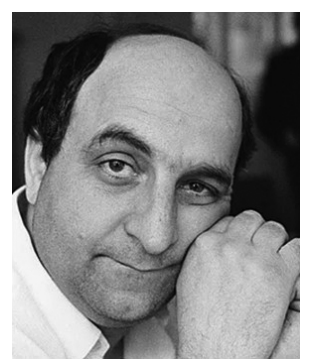

Rycina 6 Ota Pavel (1930-1973), czeski pisarz, dziennikarz i reporter sportowy

Ota Pavel, właściwie Otto Popper (1930-1973), urodził się w Pradze w rodzinie żydowskiego komiwojażera Leo Poppera. Jego biografia została ostatnio przybliżona w wydanej w naszym kraju książce Ota Pavel - pod powierzchnią (Kaczorowski, 2018). Najsłynniejszą książką Pavela jest Smrt krásnŷch srnců (Śmierć pięknych saren), mająca liczne wydania w Polsce; na jej podstawie nakręcono również film.

Na początku lat 50 . XX wieku Pavel przeżył załamanie nerwowe, prawdopodobnie epizod depresji, podczas służby wojskowej. Natomiast w roku 1964, gdy Pavel przebywał jako korespondent na zimowych igrzyskach olimpijskich w Innsbrucku, wystąpił u niego epizod maniakalny z objawami psychotycznymi o charakterze urojeń wielkościowych i prześladowczych. Pisarz był hospitalizowany w szpitalu w Pradze, a później wielokrotnie w różnych szpitalach psychiatrycznych - otrzymywał terapię elektrowstrząsową i leczenie farmakologiczne, jednak nie udało się osiągnąc istotnej poprawy. W roku 1967 doktor Pavel Grof, młody psychiatra z kliniki znajdującej się w praskiej dzielnicy Bohnice zaproponował mu leczenie za pomocą węglanu litu i przyniosło ono spektakularną poprawę. Ota Pavel opowiedział o tym wydarzeniu w liście do brata Hugona: „Pewnego dnia stał się cud. CUD. Przyszedł mój lekarz, trzymając w dłoni nowy, wspaniały proszek. A potem uścisnął mi rękę i wypuścił mnie z kliniki”. W kolejnych latach Pavel zażywał lit i napisał swoje najlepsze dzieła. Według relacji syna, istotnym objawem ubocznym terapii litem było nadmierne pragnienie powodujące wypijanie wielkich ilości płynów i znaczny przyrost masy ciała. W roku 1973 nastąpiło nagłe załamanie stanu somatycznego pisarza, ale zamiast na oddział intensywnej terapii zawieziono go na oddział psychiatryczny, gdzie zmarł.

Wspomniany tutaj Pavel (Paul) Grof w roku 1968 wyemigrował do Kanady, gdzie obecnie jest profesorem na uniwersytecie w Ottawie. Należy on do najwybitniejszych badaczy litu. W roku 1988 razem z Mogensem Schou z Danii oraz Brunem Müllerem-Oerlinghausenem z Berlina przyczynił się do założenia Międzynarodowej Grupy Badań nad Litem (ang. International Group of Study for Lithium-treated Patients, IGSLI). W artykule napisanym na 50-lecie współczesnej terapii litem wprowadził pojęcie excellent lithium responders oznaczające chorych, u których stosowanie litu jako jedynego środka normotymicznego zapobiega występowaniu nawrotów choroby przez cały okres jego stosowania, często 20 lat i dłużej, tak jakby choroba po prostu przestała istnieć (Grof, 1999).

\section{Robert Lowell}

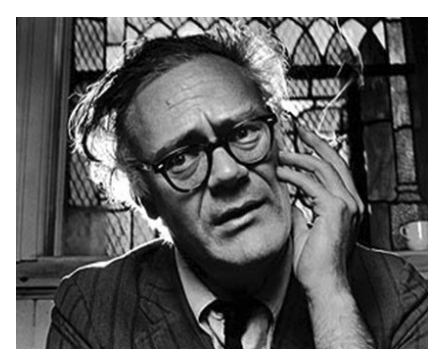

Rycina 7 Robert Lowell (1917-1977), jeden z najwybitniejszych amerykańskich poetów XX wieku, leczony litem przez ostatnie 10 lat życia

Przez ostatnie 10 lat swojego życia litem leczony był Robert Lowell (1917-1977), jeden z najwybitniejszych poetów amerykańskich XX wieku. Jego biografię przedstawiła ostatnio Kay Jamison w książce pt. Robert Lowell, setting 
the river on fire. A study of genius, mania, and character („Robert Lowell, podpalenie rzeki. Studium geniuszu manii i charakteru”), (Jamison, 2017). U Lowella choroba rozpoczęła się w 1949 roku gwałtownym stanem maniakalnym z objawami psychotycznymi, z powodu którego był hospitalizowany w szpitalu Baldpate w Georgetown, w stanie Massachusetts. Później wielokrotne przebywał w różnych szpitalach psychiatrycznych, w tym w 1958 roku w szpitalu McLean Hospital, dawniej zwanym McLean Asylum for the Insane, gdzie w roku 1845 była hospitalizowana jego prababka Harriet Lowell. Stosowanie litu rozpoczęto u Lowella w 1967 roku. Po roku jego zażywania pisał on: „Leki, które biorę, wydają się rzeczywiście zapobiegać manii. Zwykle byłbym już w szpitalu. Wielką rzeczą jest to, że nawet moje dobre życie bardzo się zmieniło, chociaż kiedyś co krok czyhało na mnie niebezpieczeństwo. Całe leczenie psychiatryczne, jakie miałem do tej pory przez niemal 19 lat, okazało się nieistotne, tak jakbym leczył złamaną nogę" (Jamison, 2017). Terapia litem działała na Lowella wielce korzystnie, a gdy odstawił na krótko lit w 1975 roku, poskutkowało to kolejnymi dwiema hospitalizacjami.

\section{Jamie Lowe}

Z ostatnich książek autobiograficznych poświęconych terapii litem należy wymienić dzieło amerykańskiej pisarki Jamie Lowe pt. Mental: lithium, love and losing my mind, opublikowanej w 2017 roku (Lowe, 2017). Dwa lata wcześniej, w dniu 25 czerwca 2015, na łamach „The New York Times Magazine" swe leczenie litem, jak również historię i gloryfikację leczenia litem przedstawiła ona $\mathrm{w}$ artykule pod prowokacyjnym tytułem I don't believe in God but I believe in lithium. Leczenie litem Jamie Lowe rozpoczęła po przebyciu psychotycznej manii w 16 . roku życia. Od tego czasu autorka kontynuowała to leczenie przez 7 lat, w międzyczasie ukończyła wydział sztuki i języka angielskiego na Uniwersytecie Kalifornii. W roku 2000 podjęła próbę odstawienia litu, co poskutkowało nasilonym epizodem maniakalnym. Ponownie zaczęła przyjmować lit i przez następne 13 lat cieszyła się dobrym samopoczuciem, była aktywna twórczo, dużo podróżowała. Nie wspomina o kontrolach przez lekarza psychiatrę i o oznaczaniu stężenia litu w tym okresie. Jesienią 2014 roku na zlecenie lekarza rodzinnego była konsultowana na ostrym dyżurze internistycznym, gdzie stwierdzono podwyższone ciśnienie, wysokie stężenie kreatyniny i objawy uszkodzenia nerek. Nefrolog zalecił jej odstawienie litu i przejście na inny lek normotymiczny. Stwierdził, że nerki funkcjonują u niej tylko w 50 proc. i jeżeli nie odstawi litu, w ciągu 10 lat grozi jej dializa i przeszczep nerki. Autorka stopniowo przeszła na stosowanie walproinianu (Depakote). W swej książce nadal jednak optymistycznie wyraża się na temat litu. Wydaje się, że optymizm mógłby być bardziej uzasadniony, gdyby leczenie litem w latach 2001-2014 było prowadzone pod kontrolą lekarza psychiatry, z okresowymi badaniami stężenia oraz wymaganymi badaniami laboratoryjnymi.

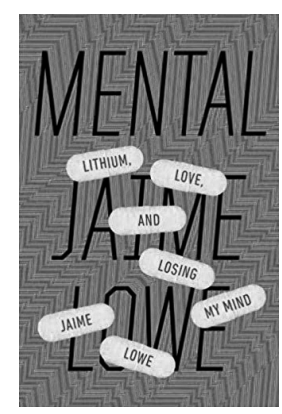

Rycina 8 Okładka książki Jamie Lowe z 2017 roku pod tytułem Mental: lithium, love and losing my mind

\section{Nicole Lyons}

Z terapią litem koresponduje ostatni wybór wierszy kanadyjskiej poetki Nicole Lyons pt. The lithium chronicles (Lyons, 2019). Nicole od kilkunastu lat zmaga się z chorobą afektywną dwubiegunową, ale jest przekonana, że choroba może stanowić okazję ku temu, aby żyć lepiej i szczęśliwiej. W tym celu stworzyła również na Facebooku stronę „The Lithium Chronicles”. Jest gorącym propagatorem podejmowania zagadnień zdrowia psychicznego oraz przeciwdziałania samobójstwom u młodzieży.

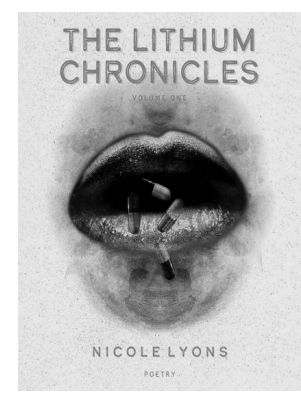

Rycina 9 Okładka zbioru poezji Nicole Lyone z 2019 roku The lithium chronicles

\section{Kurt Cobain}

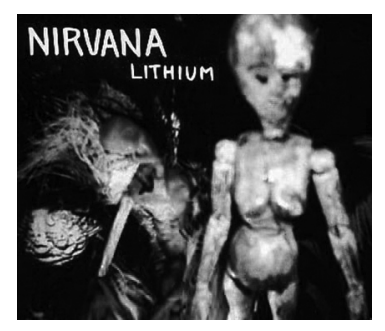

Rycina 10 Okładka płyty zespołu Nirvana, zawierającej utwór Kurta Cobaina Lithium

Utwór o nazwie Lithium został napisany w 1992 roku przez wybitnego amerykańskiego muzyka rockowego 
Kurta Cobaina (1967-1994), gitarzysty i wokalisty legendarnego zespołu Nirvana. Cobain cierpiał na chorobę afektywną dwubiegunową, był uzależniony od heroiny i prawdopodobnie zginął śmiercią samobójczą. Tytuł utworu nawiązuje do środka terapeutycznego, o którego istnieniu Cobain wiedział, ale niestety na którego zastosowanie nigdy się nie zdecydował.

\section{Sting}

Piosenka Lithium Sunset („Litowy zachód słońca”) została napisana w 1996 roku i jest wykonywana przez znanego angielskiego wokalistę Gordona Sumnera występującego pod pseudonimem Sting. Utwór nawiązuje do terapeutycznych własności litu w chorobie maniakalno-depresyjnej, m.in. w słowach „heal my soul, o, lithium sunset” („litowy zachodzie słońca, uzdrów moją duszę") oraz "take this lonesome burden of worry from my mind” („zabierz z mojego umysłu brzemię samotnego zamartwiania się"). Prawdopodobnie motywacją do powstania dzieła była chęć pomocy ludziom cierpiącym na tę chorobę.

\section{Evanescence}

Piosenka Lithium została nagrana w 2006 roku przez amerykański zespół rockowy Evancescence. Napisała ją wokalistka zespołu Amy Lee. Przesłanie jest dość przewrotne - jak gdyby autorka nie chciała, aby lit zabrał jej odczuwanie emocji, również negatywnych: „Lithium, I want to stay in love with my sorrow” („Licie, chcę pozostać zakochana w swoim smutku”). Lee przyznaje sama, że jest to swego rodzaju metafora dotycząca odczuwania szczęścia i związku twórczości artystycznej z emocjami.

\section{Omówienie}

Artykuł niniejszy pokazuje, jak istotnym lekiem w psychiatrii okazał się lit, a jego niezwykłym właściwościom dają wyraz ci, którym umożliwił on dobre, twórcze, spełnione życie, a może nawet to życie ocalił.

W artykule w pierwszej kolejności został przedstawiony australijski psychiatra John Cade, dzięki któremu wszystko się zaczęło 71 lat temu. Mimo że zaznaczył się tylko jako inicjator terapii litem we współczesnej psychiatrii, jednak już sam ten fakt zyskał po 50 latach uznanie i odzwierciedlenie w literaturze i sztuce.

W tekście pokazano sylwetki znaczących osób z obszaru literatury, nauki i sztuki, które przyjmowały lit. U niektórych z nich kliniczne efekty stosowania litu przewyższały skuteczność uprzednich terapii, niekiedy długoterminowych. Tak relacjonowali to Salvador Luria, Ota Pavel i Robert Lowell. U Jamie Lowe terapia litem pozwoliła na ukończenie studiów i działalność twórczą.

Obserwacje poczynione przez same te osoby lub przez ich bliskich wskazują również na istotne objawy niepożądane w trakcie długotrwałej terapii litem. Ota Pavel, według relacji syna, cierpiał na nadmierne pragnienie i wypijał wielkie ilości płynów. Wystąpił też u niego znaczny przyrost masy ciała. U Jamie Lowe po kilkunastu latach stosowania litu nastąpiło uszkodzenie nerek (nefropatia środmiąższowa) powodujące konieczność zmiany litu na inny lek normotymiczny (walproinian).

Ostatnie trzy przykłady wskazują natomiast, że lit przeniknął także do świata popkultury i stał się inspiracją dla utworów muzycznych Kurta Cobaina, Stinga oraz zespołu rockowego Evanescence. Tak więc podsumowując, można stwierdzić, że związek leczenia litem z literaturą i sztuką jest niebanalny i warty przedstawienia.

Czy natomiast zażywanie litu wpływa na aktywność twórczą? W roku 1979 ukazała się praca wybitnego badacza litu Mogensa Schou na ten temat, obejmująca 24 artystów. Okazało się, że połowa z nich wskazała na wzrost produktywności artystycznej w trakcie terapii litem, sześciu relacjonowało lekki spadek produktywności, a sześciu nie zauważyło żadnej zmiany (Schou, 1979). Kilka lat później Shaw i wsp. (1986), badając osoby $\mathrm{z}$ chorobą afektywną dwubiegunową w okresie eutymii, wykazali, że lit może zmniejszać zdolność do twórczych asocjacji. Jak jednak relacjonują osoby przyjmujące lit, mimo okresowego zmniejszenia u niektórych inspiracji twórczej, stosowanie litu wykazuje korzystne działanie na przebieg choroby, zapobiegając epizodom afektywnym mogącym mieć generalnie negatywne konsekwencje życiowe. W konsekwencji przekłada się to na generalnie lepsze funkcjonowanie $\mathrm{w}$ wielu sferach, $\mathrm{w}$ tym również kreatywności.
Conflict of interest and financial support non declared. / Nie zgłoszono konfliktu interesów oraz dofinansowania.

The work described in this article has been carried out in accordance with The Code of Ethics of the World Medical Association (Declaration of Helsinki) for experiments involving humans, EU Directive 2010/63/EU for animal experiments, and Uniform Requirements for manuscripts submitted to biomedical journals. / Treści przedstawione $\mathrm{w}$ artykule są zgodne z zasadami Deklaracji Helsińskiej, dyrektywami EU oraz ujednoliconymi wymaganiami dla czasopism biomedycznych.

\section{References / Piśmiennictwo}

1. Broszkiewicz J. Doktor Twardowski. Czytelnik, Warszawa, 1979. 
2. Brown W. Lithium: A Doctor, a Drug, and a Breakthrough. Liveright, New York, 2019.

3. Chiu E, Hegarty RM. John Cade: the man. Aust N Z J Psychiatry 1999; 33 Suppl: S24-S26.

4. Corcoran AC, Taylor RD, Page IH. Lithium poisoning from the use of salt substitutes. J Am Med Assoc 1949; 139: 685-688.

5. Delay J, Deniker P, Harl J-M. Utilisation en thérapeutique psychiatrique d'une phénothiazine d'action centrale elective. Ann Méd-Psychol 1952; 110: 112-131.

6. De Moore G, Westmore A (ed.) Finding Sanity: John Cade, Lithium and the Taming of Bipolar Disorder. Allen \& Unwin, Sydney, 2016.

7. Duke P, Turan K. Call me Anna: The Autobiography of Patty Duke. Bantam Books, New York, 1987.

8. Duke P, Hochman G. A Brilliant Madness; Living with Manic-Depressive Illness, Bantam Books, New York, 1992.

9. Goodwin FK, Jamison KR. Manic Depressive Illness. Oxford University Press. Oxford, 1990.

10. Goodwin FK, Jamison KR. Manic-Depressive Illness. Bipolar Disorders and Recurrent Depression. Second Edition. Oxford University Press, Oxford, 2007.

11. Grof P. Excellent lithium responders: people whose lives have been changed by lithium prophylaxis. W: Lithium: 50 Years of Psychopharmacology, New Perspectives in Biomedical and Clinical Research. Birch NJ, Gallicchio VS, Becker RW (ed.), Weidner Publishing Group, Cheshire, Connecticut, 1999:36-51.
12. Jamison KR. An Unquiet Mind. A Memoir of Moods and Madness. Alfred A. Knopf, New York, 1996.

13. Jamison KR. Touched with Fire. Manic-Depressive Illness and the Artistic Temperament. Free Press Paperback, New York, 1993.

14. Jamison KR. The Night Falls Fast. Understanding Suicide. Alfred A. Knopf, New York, 1999

15. Jamison KR. Niespokojny umysł. Pamiętnik nastrojów i szaleństwa. Zysk i S-ka, Poznań, 2000.

16. Jamison KR. Noc szybko nadchodzi. Zysk i S-ka, Poznań, 2004.

17. Jamison KR. Robert Lowell, Setting the River on Fire. A Study of Genius, Mania, and Character. Alfred A. Knopf, New York, 2017.

18. Jamison KR. Niespokojny umysł. Pamiętnik nastrojów i szaleństwa. Zysk i S-ka, Poznań, 2018.

19. Kaczorowski A. Ota Pavel - pod powierzchnią. Wydawnictwo Czarne, Wołowiec, 2018.

20. Lowe J. Mental: Lithium, Love and Losing my Mind. Blue Rider Press, New York, 2017.

21. Luria SE. A Slot Machine, a Broken Test Tube: An Autobiography. Harper and Row, New York, 1984.

22. Lyons N. The Lithium Chronicles Volume One. Indie Blu(e) Publishing, Lexington, 2019.

23. Schou M. Artistic productivity and lithium prophylaxis in manic-depressive illness. Br J Psychiatry 1979; 135: 97-103.

24. Shaw ED, Mann JJ, Stokes PE, Manevitz AZ. Effect of lithium carbonate on associative productivity and idiosyncrasy in bipolar patients. Am J psychiatry 1986; 143: 166-169. 